\title{
A Novel Effect. Changes in the Electrochemical Response of Polycrystalline Platinum Promoted by Very Fast Potential Perturbations
}

\author{
R. M. Cerviño, W. E. Triaca, and A. J. Arvia* \\ Instituto de Investigaciones Fisicoquimicas Teóricas y Aplicadas (INIFTA), Casilla de Correo 16, \\ Sucursal 4, 1900 La Plata, Argentina
}

It is well established that the voltammogram of polycrystalline platinum in acid electrolyte in the potential range corresponding to the stability of bulk water depends on the electrode history including the type of perturbation applied to the electrode and on the electrolyte composition. Thus, the voltammogram obtain ed with polycrystalline platinum in $1 \mathrm{M}$ sulphu ric acid at $25^{\circ} \mathrm{C}$ under a repetitive triangula $\overrightarrow{\mathrm{r}}$ potential sweep at $0,1 \mathrm{~V} . \mathrm{s}^{-1}$, exhibits the con ventional three regions, namely, the $\mathrm{H}-$ and $\mathrm{O}-$ adatoms electroadsorption/electrodesorption and the so-called double layer regions (Fig,1), The former region shows a multiplicity of reversible current peaks eack pair of conjugated current peaks being generally associated with the electrochemical response of a determined type of single crystal face $(1-8)$.

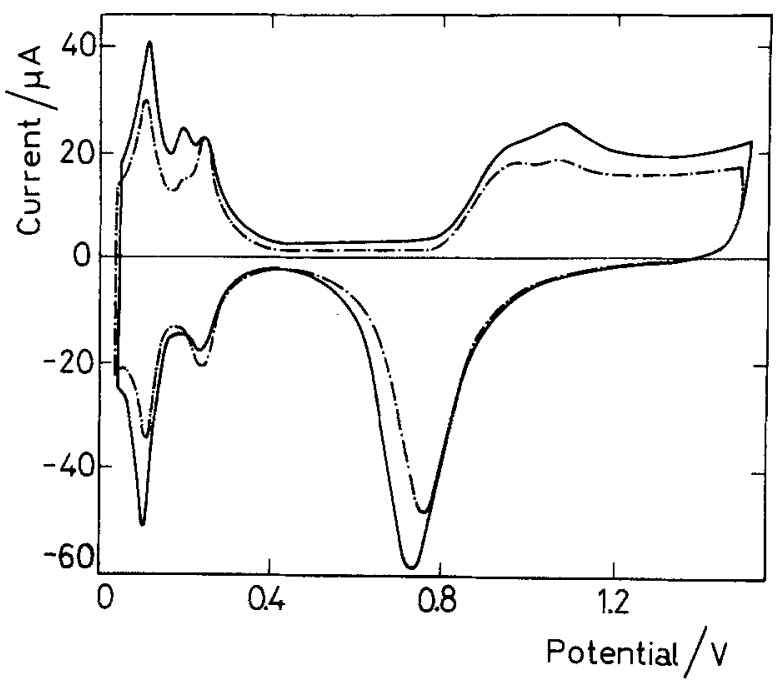

Figure 1 - Stabilized voltammograms (third cycle) run at $0.1 \mathrm{~V} . \mathrm{s}^{-1}$ in $1 \mathrm{M}$ sulphuric acid at $25^{\circ} \mathrm{C}(-)$ after $5 \mathrm{~s} \mathrm{cy}$ cling at $2000 \mathrm{~V} . \mathrm{s}^{-1}$ between 0,4 and $1.6 \mathrm{~V}$; (-.-,) polycrystalline platinum electrode.

*Electrochemical Society Active Member. Key words: platinum, oriented Pt surface, potential perturbation
When such an electrode is perturbed with a very fast repetitive triangular potential sweep at $\mathrm{v}=2000 \mathrm{~V}, \mathrm{~s}^{-1}$ between $\mathrm{E}_{\ell}=0.4 \mathrm{~V}$ and $E_{\mathrm{u}}=1.6 \mathrm{~V}$ during $5 \mathrm{~s}$, the voltammogram run immediately afterwards at $0.1 \mathrm{~V} \cdot \mathrm{s}^{-1}$ is much more similar to that of a Pt(111) single crystal surface after it has been cycled at a rela tively low $v\left(e, g, 0.1 \mathrm{~V}, \mathrm{~s}^{-1}\right)$ a few times through the anodic oxide region $(2,3,5-8)$ (Fig. 1).

On the other hand, when the potential perturbation conditions are changed to $10^{4} \mathrm{~V}, \mathrm{~s}^{-1}$ in the $0.04 \mathrm{~V}$ to $1.5 \mathrm{~V}$ range during $5 \mathrm{~min}$, the following voltammogram run at $0.1 \mathrm{~V}, \mathrm{~s}^{-1}$ in the H-adatom potential range approaches closely the characteristics described in the literature for $\mathrm{Pt}(100)$ single crystal surface $(1,3-5$, 7,8) (Fig, 2). The electrochemical characteris tics of the resulting platinum surface remain unchanged after $2 \mathrm{~h}$ cycling between $0.04 \mathrm{~V}$ and $1.5 \mathrm{~V}$ at $0.1 \mathrm{~V} \cdot \mathrm{s}^{-1}$, except for a small surface reconstruction,

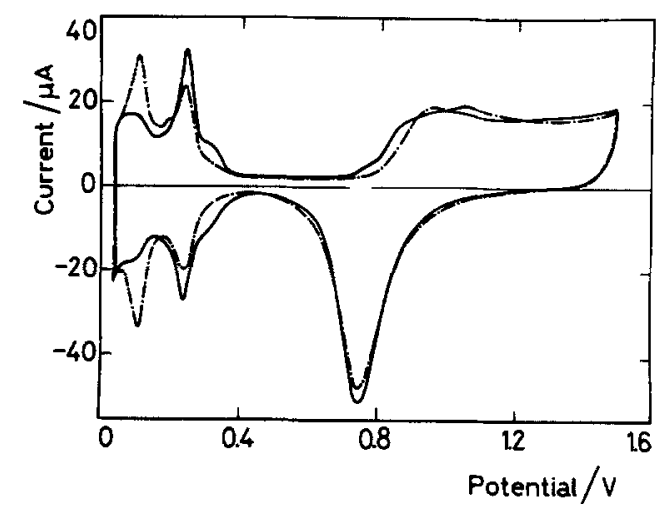

Figure 2 - Stabilized voltammograms (third cycle) run at $0.1 \mathrm{~V}, \mathrm{~s}^{-1}$ in $1 \mathrm{M}$ sulphu ric acid at $25^{\circ} \mathrm{C}(-\ldots)$ after $5 \mathrm{~min}^{-}$ cycling at $10^{4} \mathrm{~V}, \mathrm{~s}^{-1} ;(-.-n)$ polycrystalline platinum electrode.

The surface structures achieved after the potential perturbation at high $\mathrm{v}$ are stable for at least four weeks by keeping the electro de in contact with distilled water. The poly- 
crystalline structure is recovered after etching the electrode in aqua regia.

The above described experiments were made with a low resistance designed electrochemical cell consisting of a polycrystalline platinum wire working electrode (ca, $0.15 \mathrm{~cm}^{2}$ geometric area) concentrically surrounded by a large area platinum counterelectrode (ca, $50 \mathrm{~cm}^{2}$ ). The potential of the working electrode was measured against a hydrogen reference electrode in the same acid electrolyte solution. The shape of the triangular potential signal was increasingly distorted accordingly to $\mathrm{v}$ and the shift from linearity at $\left(E_{\ell}+E_{u}\right) / 2$ was ca. 10 percent at $10^{4} \mathrm{~V}, \mathrm{~s}^{-1}$.

The voltammograms run at $0.1 \mathrm{~V} \cdot \mathrm{s}^{-1}$ imply no charge increase above that corresponding to the monolayer of adsorbed either $\mathrm{H}$ or $\mathrm{O}$ atoms, at least for the platinum surface obtained after cycling at $10^{4} \mathrm{~V} \cdot \mathrm{s}^{-1}$ during $5 \mathrm{~min}$. However, for the surface resulting after cycling at $2000 \mathrm{~V}, \mathrm{~s}^{-1}$ when the duration of the potential perturbation extends to $30 \mathrm{~s}$, then a charm ge increase is noticed which is probably related to surface roughening.

The type of surface restructuring achieved during these experiments depends on $E_{\ell}, E_{u}$ and $v$. The results show that there is a frequency threshold for producing definite changes in the electrochemical response of polycrystalline platinum, which is ca. $0.5 \mathrm{kHz}$. This figure coincides with that of the repetitive square wave potential sweep which was able to produce a preferential orientation of grains at polycrystalline platinum electrodes (9) and its reciprocal was associated with the half life time of electroadsorbed $\mathrm{OH}$ species on platinum produced in the initial underpotential electro oxidation of water. Furthermore, similar changes in the electrochemical response of polycrys talline platinum as those described in the prem sent communication were also achieved by applying to the electrode in acid electrolyte other very fast periodic potential perturbations such as either a, repetitive square wave or a sinusoidal signal within the $\mathrm{H}-$ and $\mathrm{O}$ - adatom electroadsorption/electrodesorption potential range (10). Therefore, the metal surface modification promoted by the very fast potential perturbations should be related to the occurrence of the initial reversible underpotential electrooxidation of water. When the probable rate constants of the various stages involved in the 0electroadsorption are considered (11) it is con cluded that at frequencies greater than $0.5 \mathrm{kHz}$, either (0)Pt electroformation or ageing effects of the 0-adsorbed monolayer can be ignored. The latter processes are relevant when relatively slow repetitive triangular potential sweeps are applied to platinum electrodes in acid electro- lyte into the region of oxide formation. In this case, when single crystal electrodes are used, it results in oriented but atomically stepped surfaces (12). Further studies on the optical and electrocatalytic properties of these electrodes as well as the mechanism involved in the modification of their electro.. chemical response are in progress.

Acknowledgement,-

INIFTA is sponsored by the University Nacio nal de La Plata, the Consejo Nacional de Inves tigaciones Cientificas y Técnicas and the Comi sión de Investigaciones Cientificas (Provincia de Buenos Aires).

\section{REFERENCES}

1. F,G. Will, J,Electrochem.Soc, , 112, 451 (1965).

2. P,N, Ross, Jr, J,Electroanal, Chem, 76, $139(1977)$,

3. A.T, Hubbard, R,M. Ishikawa and J, Katekaru, J.Electroanal, Chem, 86, 289 (1978).

4. E. Yeager, W.E, O'Grady, M, $\vec{Y} . \mathrm{C}$, Woo and P. Hagans, J, Electrochem, Soc, , 125, 348 (1978).

5. K, Yamamoto, D.M, Kolb, R, Kotz and G. Lehmpfuh1, J,Electroanal, Chem., 96, 233 (1979).

6. J, Clavilier, R, Fauré, G, Guinet and R. Durand, J,Electroanal, Chem., 107, 205 (1980),

7. P,N, Ross, Jr, , Surf,Sci, , 102, 463 (1981).

8, F.E. Woodward, C,L, Scortichini and C.N. Reilley, J.Electroanal,Chem, 151, 109 (1983).

9. A,C. Chialvo, W.E. Triaca and A.J. Arvia, J.Electroanal, Chems, 146, 93 (1983).

10. J,C. Canullo, W.E. Triaca and A,J. Arvia, J,Electroanal, Chem, (in press),

11. J,0, Zerbino, N,R, de Tacconi, A.J. Calandra and A,J. Arvia, J.Electrochem.Soc., 124,475 (1977),

12. $\widetilde{\mathrm{F}} \mathrm{T}$. Wagner and $\mathrm{P}, \mathrm{N}$, Ross, Jr., J,Electroana 1. Chem., 150, 141 (1983).

Manuscript submitted January 1, 1984; revised manuscript received August $27,1984$.

INIFTA assisted in meeting the publication costs of this article. 